\title{
4. 高所地域高齢者の健康
}

\author{
奥宮 清人
}

\begin{abstract}
要 約 地球規模で進行する高齢化とそれに伴う生活習慣病は「身体に刻み込まれた地球環境問題」と考え られる. 高地環境に対する人間の医学生理的適応と「高地文明」とも呼びうる生態・文化的適応を明らかに し，近年の生活様式の変化がいかに老人の Quality of life（QOL）に影響を及ぼしているかを明らかにする ために, チベット高所住民の包括的な健康調査を行った．生態学的に異なるチベットの 3 地域のいずれにお いても, 伝統的な牧畜や農牧の生業から, 都市への移住などによるライフスタイルの変化により, 生活習慣 病（肥満, 高血圧, 糖尿病) の増加のみでなく, 生活機能障害や主観的 QOL の低下が見られた. 高所住民 の生活習慣病の予防と彼らの高いQOL をいかに維持していくかが今後の課題である.
\end{abstract}

Key words : 高所住民, 生活習慣病, Quality of life

（日老医誌 $2013 ； 50 ： 323-325 ）$

\section{はじめに}

人口の高齢化と生活習慣病が日本を含めて世界的に問 題となっている．高地は，人間活動に必須である酸素の 希薄さや食物確保の限界性, という厳しい側面をもつ環 境であり，そこで人間は長年に渡り医学生理学的にも文 化的にも適応してきた？その文化的適応は「高地文明」 と呼びうるものである ${ }^{11}$. 地球規模で起こっている近年 の急激な生活様式の変化の波は，一部，高地にも及んで いる. 生活習慣病の代表疾患である心筋梗塞や糖尿病は, 元来高地では少ないとされてきたが，生活様式の変化に 脆弱であるために，急速な増加も推測されており，高地 環境の老化に対する影響がさらに促進される可能性があ る. 心筋梗塞や糖尿病は酸素を全身に送りこむ循環を脅 かし，これは，低酸素適応という観点から見れば，逆行 する側面をもち,酸素の薄い高地での影響が危惧される. 一方で, 生活様式の変化が老人の寿命を延ばし，生活に 快適さをもたらす，社会経済的グローバル化の影響には このような「諸刃の剣」という側面が潜んでいる. 高所 プロジェクト（総合地球環境学研究所）は, ここ数十年 の生活の変化が高地に暮らす老人の QOL に及ほすす影響 を研究するために，下記の目的を設定した。

目的は, 高地で人はいかに生存し生活しているのか(生 老病死)，という問いに対し新たな視点を切り拓くこと

K. Okumiya : 総合地球環境学研究所
にある．地球規模で進行する高齢化とそれに伴う生活習 慣病を「身体に刻み込まれた地球環境問題」と考え，こ こに焦点をあてる．高地環境に対する人間の医学生理的 適応と「高地文明」とも呼びうる生態・文化的適応を明 らかにし, 近年の生活様式の変化がいかに老人の Quality of life（QOL）に影響を及ぼしているかを明らかにす $ろ^{233)}$.

\section{方法}

高所プロジェクトメンバーは, 現地カウンターパート と協力して調查を進めた. 手法によって医学班, 文化班, 生態班を組織し以下の課題に取り組む23).

ヒマラヤ・チベット地域（インド・ラダーク及びアル ナーチャル, 中国・青海省, ブータン) の村を対象地と した.

「身体に刻みこまれた環境問題」の解明のために，作 業仮説 1（高地適応と生活習慣病との関連）と作業仮説 2 (文明と疾病・老いとの関連) を設定し, 各班の連携, 統合をはかった，仮説検証のために，以下の 3 つのサブ テーマに基づいて研究を進めた.

（1）高地に扔ける高齢者の増加, 生活習慣病の広がり とその背景にある原因は何か.

(2) 人は高地環境に対していかに医学生理学的, 生 態・文化的に適応してきたのか.

（3）起こっている生活様式や環境の変化と, それらが 老人の well-being へ及ぼす影響はいかなるものか. 
現地機関と協力して長期滞在も含め, 上記 3 つのサブ テーマに対して以下のごとく研究を進めた.

（1）に対し，医学的健診に加え，生活習慣病の原因と なりうる文化的，生態学的因子について各村，各個人に ついて調查した．医学的，文化的，生態学的に得られた 情報を，個人単位，村単位で統合し，各因子と生活習慣 病との関連性をみだ4.

（2）に対し, 低酸素への適応について, 呼吸機能検査, 循環機能検査を主に行い，エネルギー代謝についても検 討を行うとともに，水利用，土地利用，家畜利用，道具 利用，植物利用などに注目し，聞き取り，観察を重視す る. 各利用方法の時間的変化，地域的な分布の考察を行 なった.

（3）に対し，過去と現在の経験が豊富な老人への聞き 取りを重視し，既存の客観的データの入手及び現地観測 に努め，それらを照合した。本研究の扱う夕イムスケー ルは, 現在と 5 年間のフォローアップを主軸としながら, 老人の持つ経験から約 50 年間を設定した。さらに, Visual Analogue Scale を用いて, 健康, 家族関係，友人関 係，経済状態，幸福に対する主観的な Quality of life の 評価を行なうとともに，老人及びその家族，隣人への聞 き取り，観察を通して価值観を探り，さらに客観的な健 康状態, 経済状態などの指標と合わせて考察した.

\section{結 果}

1）高地への生態・文化的適応とグローバル化による 生活様式の変化

異なる生態を代表する森のチベット：アルナーチャ ル・ブータン，オアシスのチベット：ラダーク，草原の チベット：青海の高地文明の生業と経済を比較すること により，生態の違いに適応した農林牧の戦略，生業と交 易により，地域内のみでなく広域の異なる生態を結びつ けた「つながり合うこと」の智慧と意義が明らかになっ てきた。アアルナーチャルのチベット系牧畜民においても ラドゥックとよばれる高山病があり，低酸素適応能力に より生業を家族メンバーで分担したり，老化に伴う症状 の出現や悪化が，生業やライフスタイルの変化に影響し ている事例が認められた。 アルナーチャルの標高 4,500 $\mathrm{m}$ 以下の植生と植物資源利用や在来森林管理の智慧と 外来植物の実態を明らかにした ${ }^{5}$. 老人の知恵と老人を サポートする社会の知恵 (老人智 $)^{6}$ が機能していた。 ダーク・ドムカル村では, 全世帯の土地所有・利用調查 を進め, 若年層の都市部移住に伴う耕作放棄と植林の進 行や，農牧複合の崩れとライフスタイルの変化の詳細を 明らかにした，ラダークで起こった土石流災害では，自
50 巻 3 号 $(2013: 5)$

然環境とともに近年の開発にかかわる人為的な要因につ いて明らかにしだ、.ラダーク，チャンタン高原とアル ナーチャル遊牧民の食事, 生業, 交易の季節的な移動シ ステムと生業構造とその変容を明らかにした.

2）生活習慣病の広がりと, 背景としての生活様式や 環境の変化が老人の Quality of life へ及ぼす影響

生態の違いの影響

資源の最も多様な森のチベット，草原のチベット，資 源の最もそしいオアシスのチベットの違いに適応した環 境利用による，食とライフスタイルのバランスが保たれ てきた ${ }^{8)}$. 森林資源の多いアルナーチャルとチベットと の塩などを介した交易がなされ，低地とヒマラヤ・チ ベット高地を食糧や薬用植物を介して結ぶ歴史的な中継 路として玉樹とラダークが機能していた。 それが，近年 の国際情勢により交易路や生活が変容し，高齢化とあい まって,アルナーチャル牧民やブータン高齢者の高血圧, ドムカルや玉樹市街部の糖尿病と予備群が顕在化してき た223).

経済のグローバル化と近年の生活の変化

上記ラダークの 3 地域および, 青海の 3 地域の比較に より，牧民や農牧民の市街部への定住化や換金経済への 浸透, 経済格差の増大に伴い, 肥満, 糖尿病, 高血圧の 増加と, 生活機能障害, 主観的な QOL の低下を認めた ${ }^{9}$. 自然環境の最も厳しい, ラダーク，チャンタン牧畜民に は，生業の持続の困難と市街への移動によるさらなる経 済的な QOL の低下や，新興居住地の土石流の脆弱性が 加わる二重のストレスがみられた．にもかかわらず，う つやPTSD が少ないことが明らかになり，コミュニ ティーの連帯や信仰心による精神的な支えによると思わ れた ${ }^{10)}$

高地への生理的適応の進化医学的意義

青海チベット，ラダーク高所住民と世界の他の高地住 民と比較することにより，進化的な高所適応の違いによ る，生活習慣病への影響の違いが明らかになってきた。 アルナーチャルや海晏の牧民のように, 従来の高地の生 活では，糖尿病とは無縁だが，もともと低栄養のみでな く，低酸素に適応していたがゆえに，急激なライフスタ イルの変化によって, 多血症とともに糖尿病（他の生活 習慣病も）が急激に促進されてきた。最近のチベット高 所住民にあきらかになってきた，低酸素適応遺伝子との 関連の可能性も示された2233.

3）高所住民に学ぶ豊かな老いとへルスケア・デザイン

ラダーク・ドムカルに居住する高齢者を 2 年間にわた りフォローアップすることができ, 現地医療従事者の協 力で体重, 血圧, 運動量の毎月のモニタリングにより, 
糖尿病と高血圧の地域レベルでの改善効果を認めた. ブータン・カリンで保健省と協力し, 検診と訪問により 高齢者のほほ全員をカバーした介入的研究を実践した。 高い QOL と豊かな老いをめざしたへルスケアのデザイ ンが重要である ${ }^{11}$.

\section{考察}

高地文明というべき高地に適応した，賢明な自然利用 のシステムが，近年のグローバリゼーションや温暖化の 影響により崩れつつあり，それが「身体に刻み込まれた 地球環境問題」として表面化している実態が明らかに なってきた，各地フィールド調査において，これまでに 得られた, 医学, 文化, 生態デー夕の総合的な解析を継 続しながら，現地の人々とともに日本の高齢者にも，情 報を発信して行くことが重要である。 そして，糖尿病を 始めとする生活習慣病アクセル仮説の検証を軸に，どの 部分が適応で, どの部分は過適応なのかを議論しながら， 長期のフォローアップや予後調查を, 現地の保健, 医療, 研究スタッフが継続していくことが今後の課題である.

ラダーク・ドムカルにおいては, 健康報告カードや広 報活動の充実をはかりながら，フォローアップと予後調 査を行い, 他の地域にも健康増進活動を広げている.

ブータン・カリンの高齢者に対するへルスケア・デザ インの方策を, タシガン県に広げながら，徐々に国内全 域に広げていく予定で保健省と協力を進めている. 生活 習慣病の改善, 予防効果のモニタリングをしながら, フォ ローアップ調査を継続する，さらに，生活障害者に対す るケアシステムを, チベット医学スタッフとの協力や, コミュニティーのヘルスケアのネットワーク作りと連動 して進めることが重要である.

高所住民の生活習慣病を予防しながら，彼らの高い
QOLをいかに維持していくか, そして, われわれの生 活習慣病の予防と QOL の向上にいかに生かしていくか が今後の課題である.

\section{引用文献}

1）山本紀夫：高地文明一知られざる文明. 地球環境学事典, 弘文堂, 2010, p380-381.

2）奥宮清人編：生老病死のエコロジー チベット・ヒマラ ヤに生きる，昭和堂，京都，2011，p1-241.

3）奥宮清人, 松林公蔵: 身体に刻み込まれた地球環境問題. ヒマラヤ学誌 2012; 13: 11-22.

4）月原敏博：ラダックにおける医学との境界領域研究計 画. ヒマラヤ学誌 2009; 10: 174-182.

5) Kosaka Y, Bhaskar S, Tasong M, Tag H, Riba T, Ando K: Roadside distribution patterns of invasive alien plants along an altitudinal gradients in Arunachal Himalaya, India. Mountain Research and Development 2010; 30 (3): 252-258.

6）奥宮清人：「老人智」一生老病死と高地の視点からの覚 え書き. ヒマラヤ学誌 2010;11:201-211.

7）山口哲由：山地に扔ける災害被害の変化一 2010 年 8 月 にインド北西部ラダーク管区で発生した集中豪雨被害を めぐる考察. ヒマラヤ学誌 2011; 12: 93-100.

8) Kimura Y, Okumiya K, Sakamoto R, Ishine M, Wada T, Kosaka Y, et al:: Comprehensive geriatric assessment of elderly highlanders in Qinghai, China IV: comparison of food diversity and its relation to health of Han and Tibetan elderly. Geriatr Gerontol Int 2009; 9 (4): 352-358.

9) Matsubayashi K, Kimura Y, Sakamoto R, Wada T, Ishimoto Y, Hirosaki M, et al.: Comprehensive geriatric assessment of elderly highlanders in Qinghai, China I: activities of daily living, quality of life and metabolic syndrome. Geriatr Gerontol Int 2009; 9 (4): 333-341.

10) Ishikawa $M$, Yamamoto $N$, Yamanaka G, Suwa $K$, Nakajima S, Hozo R, et al.: Disaster-related psychiatric disorders among survivors of flooding in Ladakh, India. Int J Soc Psychiatry 2012.

11) Akamoto R, Okumiya $K$, Ishine $M$, Lhadon $K$, Lhamo $S$, Rinchen S, et al:: Subjective quality of life in older community-dwelling adults in the kingdom of Bhutan and Japan. J Am Geriatr Soc 2011; 59 (11): 2157-2159.

\title{
Health status of high-altitude population
}

\author{
Kiyoto Okumiya
}

\begin{abstract}
The health status of high-altitude population in Qinghai (China), Ladakh (India), and Arunachal (India) was investigated using comprehensive geriatric functional assessment in relation to their recent lifestyle change with the socio-economic globalization. People in urban areas had a higher prevalence of lifestyle-related diseases and poorer geriatric functions, and a lower subjective quality of life (QOL) than people in rural areas. The optimal prevention of lifestyle-related diseases and preservation of a high QOL are important for the people living in each of the above-mentioned areas with a high altitude.
\end{abstract}

Key words: High-altitude population, Lifestyle-related diseases, Quality of life

(Nippon Ronen Igakkai Zasshi 2013; 50: 323-325)

Research Institute for Humanity and Nature 